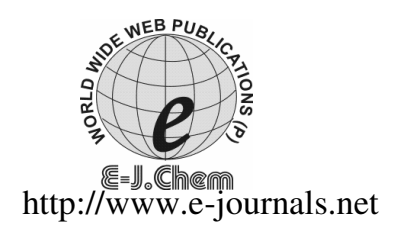

ISSN: 0973-4945; CODEN ECJHAO

E-Journal of Chemistry

2011, 8(3), 1258-1263

\title{
Synthesis, Characterization and Antimicrobial Activity of Mixed Schiff Base Ligand Complexes of $\mathrm{Co}(\mathrm{II}), \mathrm{Ni}(\mathrm{II}), \mathrm{Cu}(\mathrm{II})$ and $\mathrm{Zn}(\mathrm{II})$
}

\author{
A. K. MAPARI*, M. S. HATE and K. V. MANGAONKAR ${ }^{\#}$ \\ *Ramnarain Ruia College, Matunga (E) \\ Mumbai: - 400019, Maharashtra, India \\ "Mithibai College, Vile-Parle (W) \\ Mumbai: - 400056, Maharashtra, India \\ akmapari@gmail.com
}

Received 13 September 2010; Accepted 22 November 2010

\begin{abstract}
The mixed ligand complexes of $\mathrm{Co}(\mathrm{II}), \mathrm{Ni}(\mathrm{II}), \mathrm{Cu}(\mathrm{II})$ and $\mathrm{Zn}(\mathrm{II})$ with Schiff bases $N$-(2-hydroxy-1-naphthylidene)-4-methylaniline $\left(\mathrm{L}^{1} \mathrm{H}\right)$ and $N$-(2-hydroxybenzylidene)-2,3-dimethylaniline $\left(\mathrm{L}^{2} \mathrm{H}\right)$ have been synthesized and characterized. The resulting complexes were characterized by elemental analysis, thermogravimetric analysis, magnetic moment measurements, conductivity measurements, ${ }^{1} \mathrm{H}$ NMR, IR, UV-visible and ESR spectral studies. The Schiff bases acts as bidentate monobasic ligands, coordinating through deprotonated phenolic oxygen and azomethine nitrogen atoms. The complexes are non-electrolytic in DMSO. The presence of the two coordinated water molecules in these complexes was indicated by IR spectra and thermogravimetric analysis of the complexes. From the analytical and spectral data the stoichiometry of these complexes have been found to be $\left[\mathrm{M}\left(\mathrm{L}^{1}\right)\left(\mathrm{L}^{2}\right)\left(\mathrm{H}_{2} \mathrm{O}\right)_{2}\right]\{$ where $\mathrm{M}=\mathrm{Co}(\mathrm{II}), \mathrm{Ni}(\mathrm{II}), \mathrm{Cu}(\mathrm{II})$ and $\mathrm{Zn}(\mathrm{II})\}$. It is found that $\mathrm{Co}(\mathrm{II}), \mathrm{Ni}(\mathrm{II}), \mathrm{Cu}(\mathrm{II})$ and $\mathrm{Zn}$ (II) complexes exhibited octahedral geometry. The antimicrobial activities of ligands and their mixed ligand complexes were screened by disc diffusion method. It is found that the metal complexes have higher antimicrobial activity than the free ligand.
\end{abstract}

Keywords: Schiff bases, Mixed ligand, Metal complexes, Antimicrobial activity.

\section{Introduction}

In the field of coordination chemistry, Schiff base metal complexes have a curious history ${ }^{1,2}$. Metal ions play vital roles in a vast number of biological processes. The ions with biologically active ligands are a subject of considerable interest. Some of these compounds act via chelation ${ }^{3}$. The present work is the study of mixed ligand complexes of $\mathrm{Co}(\mathrm{II}), \mathrm{Ni}(\mathrm{II})$, $\mathrm{Cu}(\mathrm{II})$ and $\mathrm{Zn}$ (II) with Schiff bases $N$-(2-hydroxy-1-naphthylidene)-4-methylaniline $\left(\mathrm{L}^{1} \mathrm{H}\right)$ and $N$-(2-hydroxybenzylidene)-2,3-dimethylaniline $\left(\mathrm{L}^{2} \mathrm{H}\right)$. 


\section{Experimental}

All the chemicals used in the present work were of analytical grade. The metal salts used were in their hydrated form.

\section{Synthesis of ligands}

The ligands $\left(\mathrm{L}^{1} \mathrm{H}\right.$ and $\left.\mathrm{L}^{2} \mathrm{H}\right)$ were prepared by the condensation of the corresponding aldehyde and amine in 1:1 molar ratio by refluxing in distilled methanol ${ }^{4}$.

\section{Preparation of complexes}

A metal(II) chloride $(1.0 \mathrm{mmol})$ dissolved in water $(2 \mathrm{~mL})$ was added slowly with constant stirring to a solution of $N$-(2-hydroxy-1-naphthylidene)-4-methylaniline $\left(\mathrm{L}^{1} \mathrm{H}\right)(1.0 \mathrm{mmol})$ and $N$-(2-hydroxybenzylidene)-2,3-dimethylaniline $\left(\mathrm{L}^{2} \mathrm{H}\right)(1.0 \mathrm{mmol})$ in ethanol $(100 \mathrm{~mL})$. The $\mathrm{pH}$ of the solution was slowly raised to obtain the appropriate $\mathrm{pH}$ for the formation of the complex by the drop wise addition of $0.1 \mathrm{~N}$ sodium hydroxide solution. The resulting mixture was stirred for 2-3 $\mathrm{h}$. The product was digested on a hot water bath for half an hour. The complex thus formed was filtered out, washed with aqueous alcohol followed by distilled water and dried in vacuum over fused $\mathrm{CaCl}_{2}$. Similarly all the complexes were prepared. The metal estimations were carried out by standard Methods ${ }^{5}$. Elemental analysis was performed at SAIF, IIT Bombay, Mumbai. The conductance was measured in DMSO solvent on an Equiptronic EQ-660 conductivity meter. The magnetic susceptibility measurements at room temperature were made on Gouy balance using $\mathrm{HgCo}(\mathrm{NCS})_{4}$ as calibrant. The ${ }^{1} \mathrm{H}$ NMR spectrum of the ligands and $\mathrm{Zn}(\mathrm{II})$ complex was recorded on varian mercury plus $400 \mathrm{MHz}$ spectrometer using TMS as internal standard and $\left(\mathrm{D}_{6}\right)$ DMSO as a solvent. The IR spectra of ligands and their complexes were recorded on a Shimadzu FTIR $8400 \mathrm{~S}$ spectrometer in $\mathrm{KBr}$ pellets in the range of $4000-350 \mathrm{~cm}^{-1}$. UV-visible spectra were recorded on a Jasco V-530 UV-visible spectrometer in the range 200-1100 nm. Electron spin resonance spectra of powdered $\mathrm{Cu}(\mathrm{II})$ complex was recorded on varian E-112x-band ESR spectrometer using TCNE as ' $\mathrm{g}$ ' marker $(\mathrm{g}=2.0027)$ at room temperature. Thermal analysis of the metal complexes was carried out using Mettler Toledo star ${ }^{\mathrm{e}}$ SW 7.01 thermal analyzer in an inert atmosphere of nitrogen. The antimicrobial activities of ligands and their mixed ligand complexes were screened by disc diffusion method.

\section{Results and Discussion}

The elemental analysis shown in the Table 1 indicates that, all the metal complexes have 1:1:1 stoichiometry with respect to $\mathrm{L}^{1} \mathrm{H}: \mathrm{L}^{2} \mathrm{H}: \mathrm{M}$ \{where $\mathrm{M}=\mathrm{Co}(\mathrm{II}), \mathrm{Ni}(\mathrm{II}), \mathrm{Cu}(\mathrm{II})$ and $\mathrm{Zn}(\mathrm{II})\}$ and are dark colored amorphous substances, soluble in DMF and DMSO. The molar conductance values $\left(0.010-0.020 \mathrm{ohm}^{-1} \mathrm{~mol}^{-1} \mathrm{~cm}^{2}\right)$ of $10^{-3} \mathrm{M}$ solution in DMSO indicate that the metal complexes are non-electrolytic in nature.

\section{Electronic spectra and magnetic moment}

The electronic spectral studies of mixed ligand complexes of $\mathrm{Co}(\mathrm{II}), \mathrm{Ni}(\mathrm{II}), \mathrm{Cu}(\mathrm{II})$ and $\mathrm{Zn}(\mathrm{II})$ with Schiff basses $\mathrm{L}^{1} \mathrm{H}$ and $\mathrm{L}^{2} \mathrm{H}$ were carried out in DMSO solution. The absorption spectrum of the Co(II) complex shows bands at $\sim 10010 \mathrm{~cm}^{-1}(\varepsilon \sim 15)$ and $\sim 19608 \mathrm{~cm}^{-1}$ $(\varepsilon \sim 47)$ attributed to ${ }^{4} \mathrm{~T}_{1 \mathrm{~g}}(\mathrm{~F}) \rightarrow{ }^{4} \mathrm{~T}_{2 \mathrm{~g}}(\mathrm{~F})\left(v_{1}\right)$ and ${ }^{4} \mathrm{~T}_{1 \mathrm{~g}}(\mathrm{~F}) \rightarrow{ }^{4} \mathrm{~T}_{1 \mathrm{~g}}(\mathrm{P})\left(v_{3}\right)$ transitions respectively in an octahedral field ${ }^{6}$. The spectral parameters of Co(II) complex are as follows ${ }^{7}: \mathrm{Dq}=1113.27, \mathrm{~B}^{1}=718.24, \beta=0.740$ and $\beta^{0}=26 \%$. The reduction of Racah parameter from the free ion value $971 \mathrm{~cm}^{-1}$ and $\beta^{0}$ value of $26 \%$ testify the presence of considerable covalence in the complex ${ }^{8}$. 
Table 1. Physical, analytical, magnetic susceptibility and molar conductance data of the ligands and their mixed ligand complexes

\begin{tabular}{|c|c|c|c|c|c|c|c|c|}
\hline \multirow{2}{*}{$\begin{array}{l}\text { Ligand / complex, } \\
\text { molecular formula }\end{array}$} & \multirow{2}{*}{$\begin{array}{l}\text { Mol. } \\
\text { Wt. }\end{array}$} & \multirow{2}{*}{$\begin{array}{c}\text { M.P / } \\
\text { decomp. } \\
\text { temp. }{ }^{\circ} \mathrm{C}\end{array}$} & \multicolumn{4}{|c|}{ Analysis \% found (calculated) } & \multirow{2}{*}{$\begin{array}{l}\text { Magnetic } \\
\text { Moment } \\
\mu_{\text {eff B.M. }}\end{array}$} & \multirow{2}{*}{$\begin{array}{c}\lambda \\
\mathrm{Ohm}^{-1} \\
\mathrm{~cm}^{2} \mathrm{~mol}^{-1}\end{array}$} \\
\hline & & & $\mathrm{C}$ & $\mathrm{H}$ & $\mathrm{N}$ & M & & \\
\hline $\begin{array}{c}\mathrm{L}^{1} \mathrm{H} \\
\mathrm{C}_{18} \mathrm{H}_{15} \mathrm{NO}\end{array}$ & 261.32 & 132 & $\begin{array}{c}82.92 \\
(82.73)\end{array}$ & $\begin{array}{c}5.61 \\
(5.79)\end{array}$ & $\begin{array}{c}5.48 \\
(5.36)\end{array}$ & - & 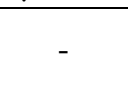 & - \\
\hline $\begin{array}{c}\mathrm{L}^{2} \mathrm{H} \\
\mathrm{C}_{15} \mathrm{H}_{15} \mathrm{NO}\end{array}$ & 225.29 & 91 & $\begin{array}{l}79.75 \\
(79.97)\end{array}$ & $\begin{array}{c}6.63 \\
(6.71)\end{array}$ & $\begin{array}{c}6.12 \\
(6.21)\end{array}$ & - & - & - \\
\hline $\begin{array}{c}{\left[\mathrm{Co}\left(\mathrm{L}^{1}\right)\left(\mathrm{L}^{2}\right)\left(\mathrm{H}_{2} \mathrm{O}\right)_{2}\right]} \\
\mathrm{C}_{33} \mathrm{H}_{32} \mathrm{~N}_{2} \mathrm{O}_{4} \mathrm{Co}\end{array}$ & 579. & $>250$ & $\begin{array}{c}68.51 \\
(68.39)\end{array}$ & $\begin{array}{c}5.32 \\
(5.57)\end{array}$ & $\begin{array}{c}4.71 \\
(4.83)\end{array}$ & $\begin{array}{c}10.33 \\
(10.17)\end{array}$ & 5.18 & 0.020 \\
\hline $\begin{array}{l}{\left[\mathrm{Ni}\left(\mathrm{L}^{1}\right)\left(\mathrm{L}^{2}\right)\left(\mathrm{H}_{2} \mathrm{O}\right)_{2}\right]} \\
\quad \mathrm{C}_{33} \mathrm{H}_{32} \mathrm{~N}_{2} \mathrm{O}_{4} \mathrm{Ni}\end{array}$ & 579.31 & 209 & $\begin{array}{c}68.33 \\
(68.42)\end{array}$ & $\begin{array}{c}5.29 \\
(5.57)\end{array}$ & $\begin{array}{c}4.72 \\
(4.84)\end{array}$ & $\begin{array}{c}10.02 \\
(10.13)\end{array}$ & 3.40 & 0.014 \\
\hline $\begin{array}{c}{\left[\mathrm{Cu}\left(\mathrm{L}^{1}\right)\left(\mathrm{L}^{2}\right)\left(\mathrm{H}_{2} \mathrm{O}\right)_{2}\right]} \\
\quad \mathrm{C}_{33} \mathrm{H}_{32} \mathrm{~N}_{2} \mathrm{O}_{4} \mathrm{Cu}\end{array}$ & 584.16 & $>250$ & $\begin{array}{c}67.73 \\
(67.85)\end{array}$ & $\begin{array}{c}5.31 \\
(5.52)\end{array}$ & $\begin{array}{c}4.65 \\
(4.80)\end{array}$ & $\begin{array}{c}10.73 \\
(10.88)\end{array}$ & 1.83 & 0.010 \\
\hline $\begin{array}{c}{\left[\mathrm{Zn}\left(\mathrm{L}^{1}\right)\left(\mathrm{L}^{2}\right)\left(\mathrm{H}_{2} \mathrm{O}\right)_{2}\right]} \\
\mathrm{C}_{33} \mathrm{H}_{32} \mathrm{~N}_{2} \mathrm{O}_{4} \mathrm{Zn} \\
\end{array}$ & 586.03 & $>250$ & $\begin{array}{c}67.47 \\
(67.63) \\
\end{array}$ & $\begin{array}{c}5.68 \\
(5.50) \\
\end{array}$ & $\begin{array}{c}4.63 \\
(4.78) \\
\end{array}$ & $\begin{array}{c}11.27 \\
(11.16)\end{array}$ & - & 0.012 \\
\hline
\end{tabular}

The Co(II) complex has magnetic moment $5.18 \mathrm{~B} \mathrm{M}$ also suggest an octahedral geometry. Ni(II) complex exhibits two electronic spectral bands at $\sim 10616 \mathrm{~cm}^{-1}(\varepsilon \sim 20)$ and $\sim 16556 \mathrm{~cm}^{-1}(\varepsilon \sim 60)$ which can be assigned to ${ }^{3} \mathrm{~A}_{2 \mathrm{~g}}(\mathrm{~F}) \rightarrow{ }^{3} \mathrm{~T}_{2 \mathrm{~g}}(\mathrm{~F})\left(v_{1}\right)$ and ${ }^{3} \mathrm{~A}_{2 \mathrm{~g}}(\mathrm{~F}) \rightarrow$ ${ }^{3} \mathrm{~T}_{1 \mathrm{~g}}(\mathrm{~F})\left(\mathrm{v}_{2}\right)$ transitions in an octahedral field ${ }^{9}$. The transition due to ${ }^{3} \mathrm{~A}_{2 \mathrm{~g}}(\mathrm{~F}) \rightarrow{ }^{3} \mathrm{~T}_{1 \mathrm{~g}}(\mathrm{P})\left(\mathrm{v}_{3}\right)$ was completely obscured by the intense intra ligand transition band. The $v_{2}: v_{1}$ ratio is 1.56 is in the usual range reported for the octahedral Ni(II) complexes ${ }^{10}$. The spectral parameters of the $\mathrm{Ni}(\mathrm{II})$ complex are as follows ${ }^{7}: \mathrm{Dq}=1061.4, \mathrm{~B}^{1}=732, \beta=0.711$ and $\beta^{0}=28.9 \%$. The reduction of Racah parameter from the free ion value $1030 \mathrm{~cm}^{-1}$ and $\beta^{0}$ value of $28.9 \%$ confirms the presence of considerable covalence in the complex ${ }^{8}$. The Ni(II) complex has magnetic moment $3.40 \mathrm{~B} \mathrm{M}$ also suggest an octahedral geometry. The $\mathrm{Cu}$ (II) complex exhibit broad band centered at $\sim 14706 \mathrm{~cm}^{-1}(\varepsilon \sim 77)$ mainly due to ${ }^{2} \mathrm{E}_{\mathrm{g}} \rightarrow{ }^{2} \mathrm{~T}_{2 \mathrm{~g}}$ transition suggesting the distorted octahedral geometry ${ }^{11}$. The observed magnetic moment value for $\mathrm{Cu}$ (II) complex is $1.83 \mathrm{~B} \mathrm{M}$ suggestive of distorted octahedral nature for the complex ${ }^{12}$. $\mathrm{Zn}$ (II) complex does not exhibit any characteristic $d$ - $d$ transitions and is also found to be diamagnetic in nature.

\section{Infrared spectra}

The important infrared frequencies exhibited by the ligands $\mathrm{L}^{1} \mathrm{H}$ and $\mathrm{L}^{2} \mathrm{H}$ and their mixed ligand complexes are given in the Table 2. Infrared spectra of the Schiff bases $\mathrm{L}^{1} \mathrm{H}$ and $\mathrm{L}^{2} \mathrm{H}$ show a broad band centered at around 3445 and $3447 \mathrm{~cm}^{-1}$ due to the phenolic hydroxyl group respectively in free ligands which disappeared in spectra of their complexes indicating probably the coordination through phenolic oxygen moiety. The Schiff bases $\mathrm{L}^{1} \mathrm{H}$ and $\mathrm{L}^{2} \mathrm{H}$ show a medium intensity band at around 1327 and $1279 \mathrm{~cm}^{-1}$ due to phenolic $v(\mathrm{C}-\mathrm{O})$ group is shifted to higher region at around 1383-1391 and 1361-1362 respectively indicating the coordination through the phenolic oxygen atoms ${ }^{13,14}$. The IR spectra of the Schiff bases ${ }^{1} \mathrm{H}$ and $\mathrm{L}^{2} \mathrm{H}$ exhibit a strong band at 1613 and $1619 \mathrm{~cm}^{-1}$ due to $v(\mathrm{C}=\mathrm{N})$ (azomethine) which has been seen shifted towards lower region at around 1614-1616 and 1600-1603 respectively in the spectra of complexes indicating the participation of the azomethine groups in the complex formation ${ }^{15}$. The spectra of the complexes show a broad diffused bands in the region at around $3100-3650 \mathrm{~cm}^{-1}$, strong bands at $1532-1537 \mathrm{~cm}^{-1}$ and week intensity bands 
at $818-829 \mathrm{~cm}^{-1}$ due to $v(\mathrm{OH}), \delta(\mathrm{OH})$ and $\rho_{\mathrm{r}}(\mathrm{OH})$ respectively of the coordinated water molecules ${ }^{6,16}$. The coordination through nitrogen of azomethine and oxygen of $(\mathrm{C}-\mathrm{O})$ group of ligands are further evidenced by the appearance in the complexes of non-ligand bands around $500-552 \mathrm{~cm}^{-1}$ and $417-464 \mathrm{~cm}^{-1}$ are due to $v(\mathrm{M}-\mathrm{O})$ and $v(\mathrm{M}-\mathrm{N})$ vibrations respectively ${ }^{16}$.

Table 2. Characteristic IR bands of the ligands $\mathrm{L}^{1} \mathrm{H}, \mathrm{L}^{2} \mathrm{H}$ and their mixed ligand complexes

\begin{tabular}{ccccccccc}
\hline \multirow{2}{*}{$\begin{array}{c}\text { Schiff base / } \\
\text { complex }\end{array}$} & \multicolumn{8}{c}{ IR bands, $\mathrm{cm}^{-1}$} \\
\cline { 2 - 10 } & $\begin{array}{c}v_{\mathrm{OH}} \\
\text { (phenolic) }\end{array}$ & $\begin{array}{c}v_{\mathrm{OH}} \\
\mathrm{H}_{2} \mathrm{O}\end{array}$ & $v_{\mathrm{C}=\mathrm{N}}$ & $\begin{array}{c}\delta_{\mathrm{OH}} \\
\left(\mathrm{H}_{2} \mathrm{O}\right)\end{array}$ & $\begin{array}{c}v_{\mathrm{C}-\mathrm{O}} \\
(\text { phenolic })\end{array}$ & $\begin{array}{c}\rho_{\mathrm{rOH}} \\
\left(\mathrm{H}_{2} \mathrm{O}\right)\end{array}$ & $v_{\mathrm{M}-\mathrm{O}}$ & $v_{\mathrm{M}-\mathrm{N}}$ \\
\hline $\mathrm{L}^{1} \mathrm{H}$ & 3445 & - & 1619 & - & 1327 & - & - & - \\
$\mathrm{L}^{2} \mathrm{H}$ & 3447 & - & 1613 & - & 1279 & - & - & - \\
{$\left[\mathrm{Co}\left(\mathrm{L}^{1}\right)\left(\mathrm{L}^{2}\right)\left(\mathrm{H}_{2} \mathrm{O}\right)_{2}\right]$} & - & $3150-$ & 1615, & 1533 & 1386, & 821 & 552, & 463, \\
& & 3650 & 1600 & 1362 & & 1300 & 418 \\
{$\left[\mathrm{Ni}\left(\mathrm{L}^{1}\right)\left(\mathrm{L}^{2}\right)\left(\mathrm{H}_{2} \mathrm{O}\right)_{2}\right]$} & - & $3200-$ & 1616, & 1537 & 1383, & 818 & 548, & 461, \\
& & 3650 & 1603 & 1361 & & & 503 & 417 \\
{$\left[\mathrm{Cu}\left(\mathrm{L}^{1}\right)\left(\mathrm{L}^{2}\right)\left(\mathrm{H}_{2} \mathrm{O}\right)_{2}\right]$} & - & $3150-$ & 1614, & 1532 & 1385, & 821 & 547, & 461, \\
& & 3650 & 1601 & 1361 & & & 502 & 419 \\
{$\left[\mathrm{Zn}\left(\mathrm{L}^{1}\right)\left(\mathrm{L}^{2}\right)\left(\mathrm{H}_{2} \mathrm{O}\right)_{2}\right]$} & - & $3100-$ & 1616, & 1536 & 1391, & 829 & 549, & 464, \\
\hline
\end{tabular}

\section{${ }^{l} H$ NMR spectra}

The ${ }^{1} \mathrm{H}$ NMR spectrum of the ligand $\left(\mathrm{L}^{1} \mathrm{H}\right)$ showed singlet at $15.412 \delta(\mathrm{s}, 1 \mathrm{H}, \mathrm{OH})$ due to proton of phenolic $-\mathrm{OH}$ group. The azomethine proton have resonated as singlet at $9.593 \delta$ $(\mathrm{s}, 1 \mathrm{H}, \mathrm{CH}=\mathrm{N})$. The ten aromatic protons have resonated in the region $6.946-8.434 \delta$ $(\mathrm{m}, 10 \mathrm{H}, \mathrm{Ar}-\mathrm{H})$ as multiplet. The three protons of methyl group resonated as singlet at 2.312 $\delta\left(\mathrm{s}, 3 \mathrm{H}, \mathrm{Ar}-\mathrm{CH}_{3}\right)$. The ${ }^{1} \mathrm{H}$ MR spectrum of the ligand $\left(\mathrm{L}^{2} \mathrm{H}\right)$ showed singlet at $13.291 \delta \quad(\mathrm{s}$, $1 \mathrm{H}, \mathrm{OH})$ due to proton of phenolic $-\mathrm{OH}$ group. The azomethine proton have resonated as singlet at $8.77 \delta(\mathrm{s}, 1 \mathrm{H}, \mathrm{CH}=\mathrm{N})$. The seven aromatic protons have resonated in the region $6.956-7.622 \delta(\mathrm{m}, 7 \mathrm{H}, \mathrm{Ar}-\mathrm{H})$ as multiplet. The six protons of two methyl groups resonated as two singlets at $2.198 \delta\left(\mathrm{s}, 3 \mathrm{H}, \mathrm{Ar}-\mathrm{CH}_{3}\right)$ and $2.251 \delta\left(\mathrm{s}, 3 \mathrm{H}, \mathrm{Ar}-\mathrm{CH}_{3}\right)$.

The ${ }^{1} \mathrm{H}$ NMR spectrum of the $\mathrm{Zn}(\mathrm{II})$ complex showed two singlet at $9.427 \delta(\mathrm{s}, 1 \mathrm{H}$, $\mathrm{CH}=\mathrm{N})$ and $8.425 \delta(\mathrm{s}, 1 \mathrm{H}, \mathrm{CH}=\mathrm{N})$ due to protons two azomethine group. The seventeen aromatic protons have resonated in the region $6.681-8.240 \delta(\mathrm{m}, 17 \mathrm{H}, \mathrm{Ar}-\mathrm{H})$ as multiplet. The nine protons of three methyl groups resonated as three singlets at $2.191 \delta(\mathrm{s}, 3 \mathrm{H}, \mathrm{Ar}-$ $\left.\mathrm{CH}_{3}\right)$ and $2.078 \delta\left(\mathrm{s}, 3 \mathrm{H}, \mathrm{Ar}-\mathrm{CH}_{3}\right), 1.861 \delta\left(\mathrm{s}, 3 \mathrm{H}, \mathrm{Ar}-\mathrm{CH}_{3}\right)$. The proton of phenolic $-\mathrm{OH}$ group which was observed at $15.412 \delta(\mathrm{s}, 1 \mathrm{H}, \mathrm{OH})$ and $13.291 \delta(\mathrm{s}, 1 \mathrm{H}, \mathrm{OH})$ for Schiff bases $\mathrm{L}^{1} \mathrm{H}$ and $\mathrm{L}^{2} \mathrm{H}$ respectively has disappeared in $\mathrm{Zn}$ (II) complex, indicating coordination through phenolic oxygen moiety to the metal ion via deprotonation ${ }^{17}$.

\section{Thermogravimetric analysis}

The dynamic TGA with the percentage mass loss at different steps have been recorded. The elimination of lattice and coordinated water molecules take place in the first step. The $\mathrm{Co}(\mathrm{II}), \mathrm{Ni}(\mathrm{II}), \mathrm{Cu}(\mathrm{II})$ and $\mathrm{Zn}(\mathrm{II})$ complexes lose their weight in the temperature range $~ 130$ $270{ }^{\circ} \mathrm{C}, 125-250{ }^{\circ} \mathrm{C}, 120-260{ }^{\circ} \mathrm{C}$ and $135-275{ }^{\circ} \mathrm{C}$ respectively corresponding to two coordinated water molecules with an endothermic peak in DTA curve. After the total loss of water, the organic moiety decomposes on further increment of temperature. The complete decomposition of ligands occurs at $\sim 450-650{ }^{\circ} \mathrm{C}$ and the observed residue corresponds to the 
respective metal oxide ${ }^{18}$. The occurrence of endothermic peak and elimination of the two water molecules at comparatively higher temperature unambiguously confirm our earlier observation based upon the IR spectrum that the water molecules are coordinated in the metal complexes.

\section{ESR spectra}

The ESR spectrum of the powdered sample of the $\mathrm{Cu}$ (II) complex was recorded at room temperature. The observed value for the $\left[\mathrm{Cu}\left(\mathrm{L}^{1}\right)\left(\mathrm{L}^{2}\right)\left(\mathrm{H}_{2} \mathrm{O}\right)_{2}\right]$ complex are $\mathrm{g}_{\|}=2.134, \mathrm{~g}_{\perp}=2.086$ and $\mathrm{G}=1.571$. The observed $\mathrm{g}_{\|}$value is less than 2.3 in agreement with the covalent character of the metal - ligand bond ${ }^{8}$. The trend $g_{\|}>g_{\perp}>g_{e}$ (2.0023) observed for this complex shows that the unpaired electron is localized in $\mathrm{d}_{\mathrm{x}-\mathrm{y}}^{2}$ orbital of $\mathrm{Cu}(\mathrm{II})$ ion and the spectral features are characteristic of axial symmetry; tetragonal elongated structure may be assumed for this $\mathrm{Cu}$ (II) complex $^{8,19}$. The anisotropic $G$ values have been calculated by using the equation $\mathrm{G}=\left(\mathrm{g}_{\|}-2.002\right) /\left(\mathrm{g}_{\perp}-2.002\right)$. If the $\mathrm{G}$ value is less than 4.0, the ligand forming the copper(II) complex is regarded as strong field ligand while a value of $\mathrm{G}$ greater than 4.0 indicates weak field ligand. As $\mathrm{G}=1.571$ for the present complex indicates that the ligands $\mathrm{L}^{1} \mathrm{H}$ and $\mathrm{L}^{2} \mathrm{H}$ are strong field ligands and the metal-ligand bonding in this complex is covalent ${ }^{8}$.

\section{Antimicrobial activity}

Synthesized Schiff bases and their corresponding mixed ligand metal complexes were screened against E. coli, S. aurious, B. subtilis and S. typhi to assess their potential as antimicrobial agent by disc diffusion method. The zones of inhibition based upon zone size around the discs were measured. The measured zone of inhibition against the growth of various microorganisms is listed in Table 3. It is found that the metal complexes have higher antimicrobial activity than the free ligand. Hence complexation increases the antimicrobial activity $^{20}$. Such increased activity of the metal complexes can also be explained on the basis of chelation theory ${ }^{21}$.

Table 3. Antimicrobial activity data of the ligands $\mathrm{L}^{1} \mathrm{H}, \mathrm{L}^{2} \mathrm{H}$ and their mixed ligand complexes

\begin{tabular}{ccccc}
\hline \multirow{2}{*}{ Schiff base / complex } & \multicolumn{4}{c}{ Zone of inhibition, mm } \\
\cline { 2 - 5 } & S.aureus & B.subtilis & E.coli & S.typhi \\
\hline $\mathrm{L}_{1} \mathrm{H}$ & 2.5 & 2.6 & 2.7 & 0.0 \\
$\mathrm{~L}_{6} \mathrm{H}$ & 0.0 & 2.5 & 2.8 & 2.6 \\
{$\left[\mathrm{Co}\left(\mathrm{L}^{1}\right)\left(\mathrm{L}^{2}\right)\left(\mathrm{H}_{2} \mathrm{O}\right)_{2}\right]$} & 7.5 & 6.5 & 4.5 & 6.8 \\
{$\left[\mathrm{Ni}\left(\mathrm{L}^{1}\right)\left(\mathrm{L}^{2}\right)\left(\mathrm{H}_{2} \mathrm{O}\right)_{2}\right]$} & 4.5 & 8.5 & 7.0 & 8.2 \\
{$\left[\mathrm{Cu}\left(\mathrm{L}^{1}\right)\left(\mathrm{L}^{2}\right)\left(\mathrm{H}_{2} \mathrm{O}\right)_{2}\right]$} & 3.3 & 4.5 & 5.7 & 6.2 \\
{$\left[\mathrm{Zn}\left(\mathrm{L}^{1}\right)\left(\mathrm{L}^{2}\right)\left(\mathrm{H}_{2} \mathrm{O}\right)_{2}\right]$} & 4.3 & 8.3 & 10.3 & 8.3 \\
\hline
\end{tabular}

\section{Conclusion}

The elemental analysis, magnetic susceptibility, electronic, ${ }^{1} \mathrm{H}$ NMR, IR and ESR spectral observations suggest the octahedral geometry for the $\mathrm{Co}(\mathrm{II}), \mathrm{Ni}(\mathrm{II}), \mathrm{Cu}$ (II) and $\mathrm{Zn}$ (II) complexes and exhibit coordination number six. The general structure of the complexes is shown in Figure 1. The Schiff's bases do show some antimicrobial activity to certain extent but their complexes exhibit comparatively greater amount of activity against the microorganisms. 


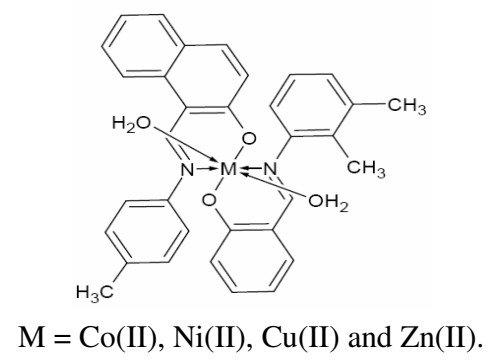

Figure 1. Proposed structure for the complexes

\section{Acknowledgment}

One of the authors (A. K. M.) is grateful to UGC.WRO, Pune for the award of teacher fellowship.

\section{References}

1. Yamada S, Coord Chem Rev., 1999, 537, 190-192.

2. Singh S, Das S and Dhakarey R, E-J Chem., 2009, 6(1), 99-105.

3. Albert A, Selective Toxicity: The Physicochemical Basis of Therapy, $6^{\text {th }}$ Ed., Chapaman and Hall, Londan, 1979.

4. Viroopakshappa J and Rao D V, J Indian Chem Soc., 1996, 73, 531-532.

5. Vogel A I, Text Book of Quantitative Practical Inorganic Chemistry, ELBS, 1984.

6. Dash D C, Meher F M, Monhanty P C and Nanda J, Indian J Chem., 1987, 26(A), 698-701.

7. Liver A B P, Inorganic electronic spectroscopy. Elsevier, New York, 1984.

8. Dutta R L, Syamal A, Elements of Magnatochemistry, $2^{\text {nd }}$ Ed., East west press, New Delhi, 1996.

9. Mahapatra B B and Patel B K, Indian J Chem., 1987, 26(A), 623-624.

10. Makode J T and Aswar A S, Indian J Chem., 2004, 43(A), 2120-2125.

11. Campbell M J M and Grzeskowiak R, J Chem Soc A, 1967, 396.

12. Biradar N S and Havinale B R, Inorg Chem Acta., 1979, 17, 157-160.

13. Canpolat E and Kaya M, Russian J Coord Chem., 2005, 31, 415.

14. Saxena A and Tandon J P, Polyhedron, 1984, 3, 681.

15. Kiramany K, Prashanthi Y, Subhashini N J P and Shivraj, J Chem Pharm Res., 2010, 2(1), 375-384.

16. Nakamato K, Infrared Spectra of Inorganic and Coordination Compounds, John Wiley, New York, 1970.

17. Reddy V, Patil N and Angadi S D, E-J Chem., 2008, 5(3), 577-583.

18. Panda A K, Dash D C, Mishra P and Mohanty H, Indian J Chem., 1996, 35(A), 324-327

19. Thakkar N V, Bootwala S Z, Ind J Chem., 1995, 34(A), 370-374.

20. Anjaneyula Y and Rao P P, Synth React Inorg Met Org Chem., 1986, 26, 257.

21. Thimmaiah K N, Lloyd W D and Chandrappa G T, Inorg Chim Acta, 1985, 81, 106. 


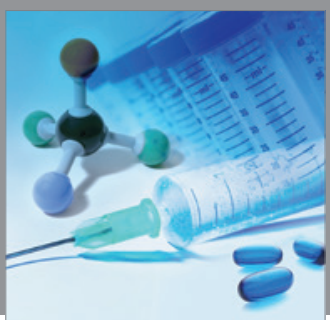

International Journal of

Medicinal Chemistry

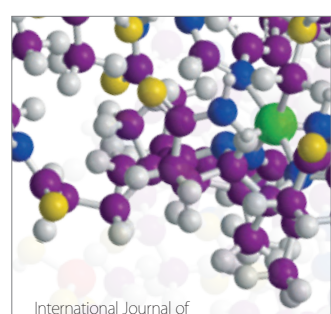

Carbohydrate Chemistry

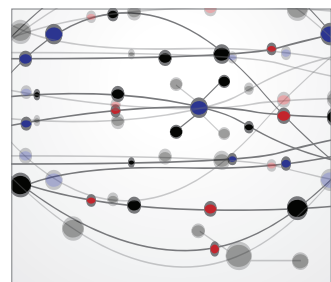

The Scientific World Journal
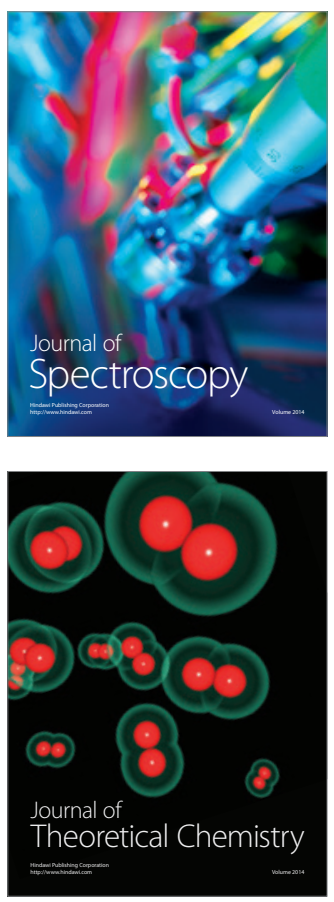
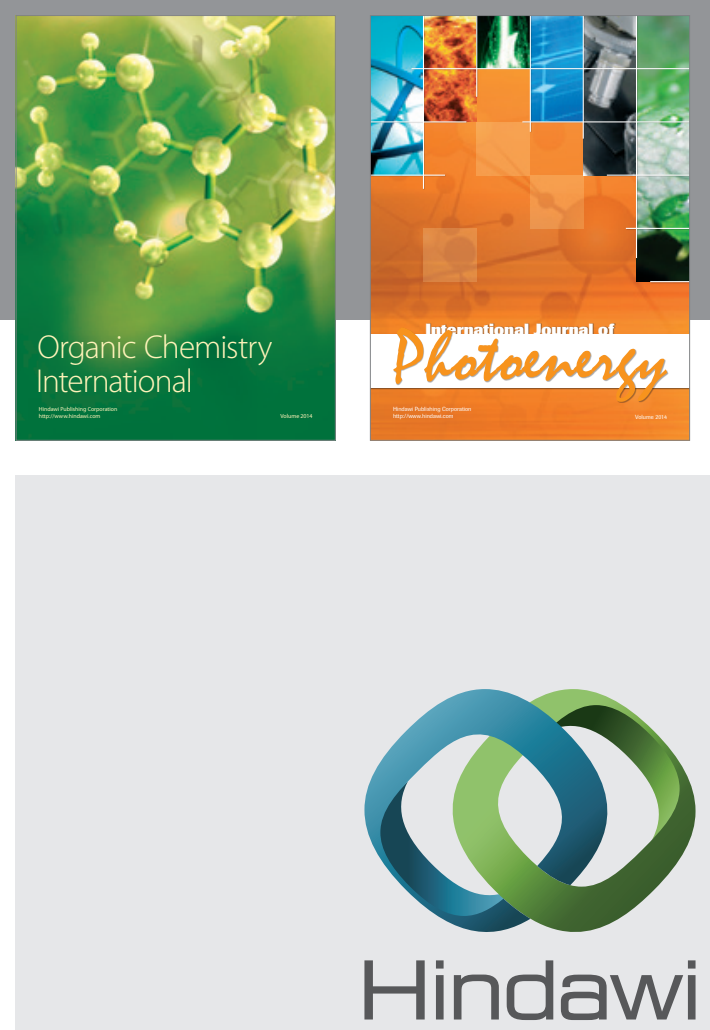

Submit your manuscripts at

http://www.hindawi.com
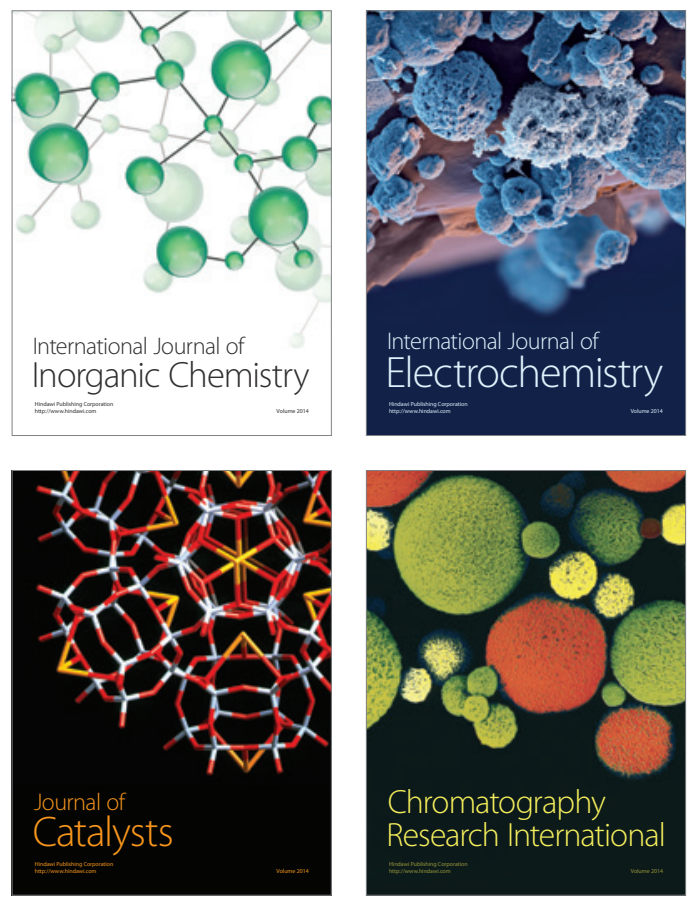
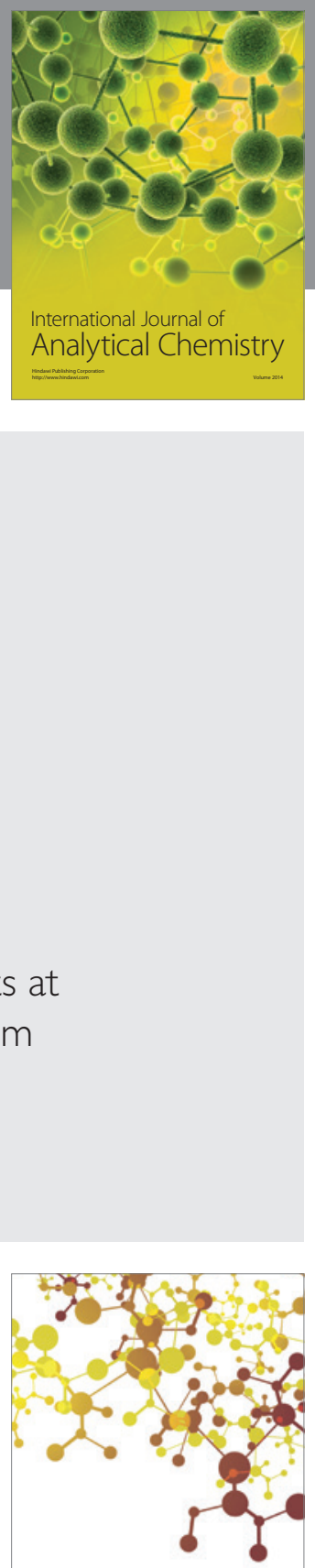

Journal of

Applied Chemistry
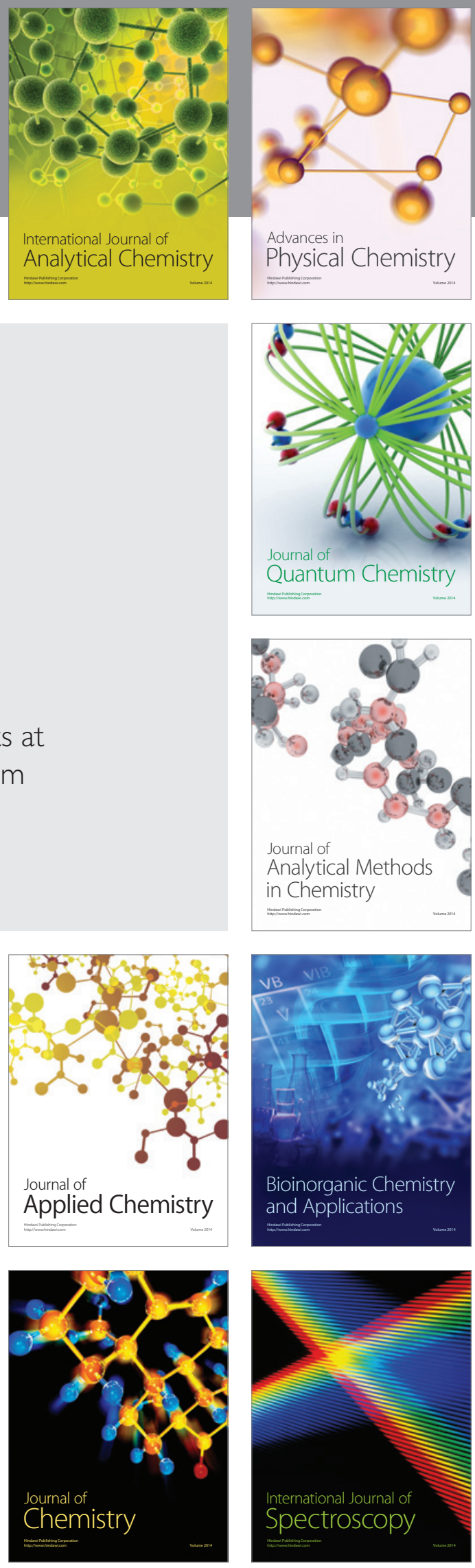